[Chem. Pharm. Bull.

35( 3$) 1289-1293(1987)]$

\title{
Potentiating Effect of $\beta$-Glucan from Cochliobolus miyabeanus on Host-Mediated Antitumor Activity in Mice
}

\author{
Hiroaki Nanba* and Hisatora Kuroda \\ Laboratory of Microbiology, Kobe Women's College of Pharmacy, \\ Motoyama, Higashinada, Kobe 658, Japan
}

(Received August 27, 1986)

\begin{abstract}
The polysaccharide As-I, a $\beta-1,3$ glucan possessing 1,6-linked side chains, isolated from mycelia of Cochliobolus miyabeanus (Ascomycetes), inhibited the growth of Sarcoma 180 solid tumor in ICR mice. As-I also inhibited the growth of solid tumors of IMC-carcinoma in $\mathrm{CDF}_{1}$ mice by $32 \%$ and that of solid tumors of MM-46 carcinoma in $\mathrm{C} 3 \mathrm{H}$ mice by $99.3 \%$ at $0.1 \mathrm{mg} / \mathrm{kg} / \mathrm{d}(10$ times). However, As-I has no direct cytotoxic activity against tumor cells. The effect of As-I on macrophages was studied, because branched $\beta-1,3$ glucans may stimulate cellular immunity. As-I activated macrophage spreading and phagocytosis of tumor cells. Accordingly, the antitumor activity of As-I might be host-mediated, like that of other $\beta-1,3$ glucans.
\end{abstract}

Keywords_Cochliobolus miyabeanus; $\beta-1,3$ glucan; antitumor activity; macrophage activation; phagocytic activity

In the previous paper, ${ }^{1)}$ we described the isolation of $\beta$-glucan possessing 1,6-linked side chains from the mycelia of Cochliobolus miyabeanus (Ascomycetes) and showed that it inhibited the growth of Sarcoma 180 solid tumor in ICR mice. According to Chihara et al, ${ }^{2)}$ small doses of lentinan isolated from shiitake (Lentinus edodes), the chemical structure of which resembles that of this glucan, caused some regression of various syngeneic tumors in mice and its combined use with chemotherapeutic agents prolonged the survival of mice bearing syngeneic tumors. In the present investigation, the $\beta$-glucan obtained from the mycelia of Cochliobolus miyabeanus inhibited the growth of syngeneic tumors and activated macrophages.

\section{Materials and Methods}

Animals-Male mice of ICR (4 weeks old), C3H, CDF 1 , BALB/C and C57BL/6N (6 weeks old) straines purchased from Charles River Japan were raised for 1 week before being used for tests.

Tumors-MM-46 tumor cells were transplanted into male $\mathrm{C} 3 \mathrm{H}$ mice, IMC-carcinoma cells into $\mathrm{CDF}_{1}$ mice, $^{-}$ Meth-A fibrosarcoma cells into BALB/C mice, B-16 melanoma and Lewis Lung carcinoma into C57BL/6N mice and Sarcoma 180 cells into ICR mice, in the axilla. In all experiments, $2 \times 10^{6}$ tumor cells were transplanted s.c.

Collection of Macrophages from the Peritoneal Cavity - The peritoneal cavity of a mouse was washed with Hanks' solution and the washings were centrifuged at $1200 \mathrm{rpm}$ for $10 \mathrm{~min}$. Cells from the pellet were suspended in RPMI 1640 medium and $1.0 \times 10^{6}$ cells per well were inoculated onto a 24 -well plastic plate (Linbro, Flow Lab.). The plate was incubated at $35^{\circ} \mathrm{C}$ in a $5 \% \mathrm{CO}_{2}$ atmosphere. As macrophages were firmly adherent after $30 \mathrm{~min}$ in culture, non-adherent cells were removed by washing with Hank's solution 3 times. A $1 \mathrm{ml}$ portion of RPMI 1640 medium was added to each well and the macrophages were incubated in a $5 \% \mathrm{CO}_{2}$ atmosphere as above. The cells were fixed for $2 \mathrm{~h}$ with glutaraldehyde and 3 times more in $\mathrm{MeOH}$, followed by staining with Giemsa. The number of spreading cells was determined by examining 200 cells per sample at random. ${ }^{3}$ For the evaluation of phagocytic activity, $1 \times 10^{7}$ fluorescein-Listeria or latex particles were added to glass-adherent cells, and $60 \mathrm{~min}$ later, extracellular Listeria or latex particles were rinsed away with phosphate buffered saline (PBS). The number of intracellular particles per 200 cells was counted to assess the phagocytic activity. ${ }^{4)}$

Preparation of Fluorescein Listeria_L Listeria were inoculated into nutrient broth medium containing $0.1 \mathrm{ml}$ of fluorescein solution and cultured at $37^{\circ} \mathrm{C}$ for $16 \mathrm{~h}$. After centrifugation ( $1500 \mathrm{rpm}, 20 \mathrm{~min}$ ), the bacterial sediment was 
washed and heated at $98^{\circ} \mathrm{C}$ for $15 \mathrm{~min}$. The bacteria were suspended in saline.

\section{Results and Discussion}

A dose of 0.5 or $1.0 \mathrm{mg} / \mathrm{kg} / \mathrm{d}$ of As-I was injected i.p. into mice daily for $9 \mathrm{~d}$, starting at $24 \mathrm{~h}$ after the implantation of Sarcoma 180 tumor cells. The solid tumor masses were removed and weighed $30 \mathrm{~d}$ after the implantation. The extents of tumor growth inhibition were $49.7 \%$ and $26.2 \%$, respectively, while the extent of inhibition at $0.5 \mathrm{mg} / \mathrm{kg} / \mathrm{d}$ of lentinan was $42.8 \%$. On the other hand, glycoprotein consisting of $61 \%$ protein and $39 \%$ glucan from mycelia showed essentially no antitumor action at $0.5 \mathrm{mg} / \mathrm{kg} / \mathrm{d}$.

The dependence of the antitumor effect of As-I on the period of administration was next examined. The inhibition was $51.8 \%$ when As-I was injected i.p. daily for $9 \mathrm{~d}$ starting at $24 \mathrm{~h}$ after the tumor implantation, and it was still as high as $37.1 \%$ when As-I was injected daily 9 times from 1 week after the tumor implantation. As-I, however, showed no antitumor activity at all when daily injection for $3 \mathrm{~d}$ was repeated 3 times at 3 -d intervals after the implantation, when $4.5 \mathrm{mg}$ was injected at once immediately after the implantation, or when $2.25 \mathrm{mg}$ of As-I was injected twice. These results indicate that As-I should be administered (i.p.) successively for a certain period in certain doses in order to exert antitumor action.

The effects of As-I on syngeneic tumors were examined. In mice in which Meth-A fibrosarcoma (in BALB/C mice), Lewis Lung carcinoma or B-16 melanoma (in C57BL/6N mice) were implanted i.p., no prolongation of the survival was found in terms of the time required for half of the mice in a group to die. In contrast, As-I inhibited the growth of solid tumors of IMC-carcinoma in $\mathrm{CDF}_{1}$ mice by $32 \%$ and that of solid tumors of MM-46 carcinoma in $\mathrm{C} 3 \mathrm{H}$ mice by as much as $95.2 \%(25 \%$ complete regression) and $99.3 \%(75 \%$ complete regression) at 0.1 and $0.5 \mathrm{mg} / \mathrm{kg} / \mathrm{d}$, respectively as shown, in Table I. These results show that As-I is effective against some syngeneic tumors. However, the tumor growth recurred when the mice were left without treatment for 3 weeks after the disappearance of the tumor. Whether or not the antitumor activities of As-I depend on cytotoxic activity or immunostimulating activity was studied. MM-46 carcinoma cells were collected from the peritoneal cavity of tumor-bearing $\mathrm{C} 3 \mathrm{H}$ mice and harvested by centrifugation at $1200 \mathrm{rpm}$ for $10 \mathrm{~min}$. Isolated tumor cells were suspended in Hanks' solution with $50 \mu \mathrm{g} / \mathrm{ml} \mathrm{As-I} \mathrm{to}$ give a concentration of $3 \times 10^{6}$ cells $/ \mathrm{ml}$. The suspension was incubated in a $5 \% \mathrm{CO}_{2}$ atmosphere for periods ranging from 0 to $90 \mathrm{~min}$. After the incubation, the cells were collected and rinsed in Hanks' solution. Then $2 \times 10^{6}$ cells were implanted (s.c.) into $\mathrm{C} 3 \mathrm{H}$ mice, and after $32 \mathrm{~d}$ the tumor mass was removed and weighed. No significant difference was observed between tumors arising from cells treated with As-I and those from intact cells receiv-

TABLE I. Antitumor Effects of As-I against Various Syngeneic Tumors

\begin{tabular}{|c|c|c|}
\hline \multirow[b]{2}{*}{ Tumor } & \multicolumn{2}{|r|}{ Antitumor activity } \\
\hline & $\begin{array}{l}\text { Ascites } \\
\text { type }^{a)}\end{array}$ & $\begin{array}{l}\text { Solid } \\
\text { type }^{b)}\end{array}$ \\
\hline Meth-A fibrosarcoma in BALB/C mouse & +11.5 & $23.8^{e)}$ \\
\hline B-16 melanoma in C57BL/6N mouse & -5.8 & 21.3 \\
\hline Lewis lung carcinoma in $\mathrm{C} 57 \mathrm{BL} / 6 \mathrm{~N}$ mouse & +13.2 & 10.4 \\
\hline IMC carcinoma in $\mathrm{CDF}_{1}$ mouse & +17.4 & $32.0^{b)}$ \\
\hline \multirow[t]{2}{*}{ MM-46 carcinoma in $\mathrm{C} 3 \mathrm{H}$ mouse } & +26.8 & $95.2(25 \% \text { complete regression })^{c . f)}$ \\
\hline & +29.5 & $99.3(75 \% \text { complete regression })^{d, e)}$ \\
\hline
\end{tabular}

a) ILS of median survival (\%). b) Inhibition (\%). c,d) As-I administered on days $1-9(c, 0.5 \mathrm{mg} / \mathrm{kg}$; $d, 0.1 \mathrm{mg} / \mathrm{kg}$ ). $\quad t$-Test: $e$ ) $p<0.05, f) p<0.01$. 
TABLE II. Spreading Rate of Macrophages Treated with As-I

\begin{tabular}{lcc}
\hline \hline Sample & Dose $(\mu \mathrm{g} / \mathrm{ml})$ & Spreading rate \\
\hline Saline (control) & - & 1.00 \\
As-I & 10 & $1.98^{a)}$ \\
& 100 & $1.55^{b)}$ \\
Laminarin & 10 & 1.14 \\
& 100 & $0.97^{a)}$ \\
Lentinan & 10 & $2.17^{b)}$ \\
& 100 & $1.77^{b)}$ \\
\hline
\end{tabular}

Spreading rate $=$ No. of spreading cells $/$ total cells. $t$-Test: $a$ ) $p<0.05, b) p<0.01$.

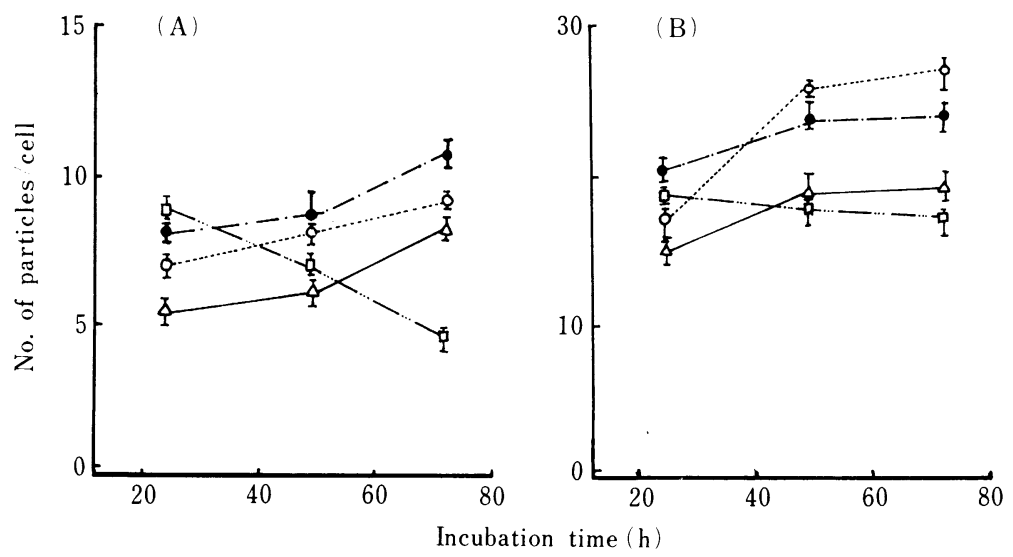

Fig. 1. Phagocytic Activities of (A) Latex Particles and (B) Fluorescein-Listeria by Macrophages

O, $10 \mu \mathrm{g} / \mathrm{ml} \mathrm{As-I;} \bullet, 50 \mu \mathrm{g} / \mathrm{ml}$ As-I; $\square, 50 \mu \mathrm{g} / \mathrm{ml}$ lentinan; $\triangle$, control (saline).

ing no treatment. This indicates that tumor cells treated with As-I were capable of growing. Namely, this result suggests that As-I exerts no direct cytotoxic action against tumor cells. The effect of As-I on macrophages was next studied, because the antitumor activity of As-I required a certain period after treatment for its manifestation, and structurally related lentinan can activate cellular immunity. ${ }^{5-7)}$ The activation of macrophages was assessed in terms of spreading rate. Macrophages were collected $24 \mathrm{~h}$ after subcutaneous injection of As-I into the femoral region of ICR mice. The macrophages were fixed and stained, and spreading ones were counted. Being adherent to glass and extended to form a distinctive shape, activated macrophages are readily distinguishable from non-activated ones. The number of spreading macrophages approximately doubled after treatment with $10 \mu \mathrm{g} / \mathrm{ml}$ As-I. Laminarin, which has no antitumor action, could not activate macrophages (Table II).

In order to determine whether the activation of macrophages involves direct action of As-I or is an indirect function mediated by other cells (e.g. T lymphocytes, NK cells), the effect of As-I on phagocytosis of fluorescein-Listeria and latex particles was studied in vitro. To increase the yields of macrophages, $3.0 \mathrm{ml}$ of $1.5 \%$ methylcellulose $(\mathrm{MC}, 4000 \mathrm{cP})$, an inducer, was injected into the peritoneal cavity of ICR mice. In peritoneal cells harvested one day after the injection, neutrophils were dominant, while macrophages were not mature and resembled monocytes. After 3-4d, however, the yield of mature macrophages increased to about 20 times that for untreated mice. After cultivation, the macrophages induced by methylcellulose 
Table III. Phagocytosis of Latex Particles

\begin{tabular}{lcc}
\hline \hline Sample & Dose $(\mu \mathrm{g} / \mathrm{ml})$ & $\begin{array}{c}\text { Phagocytic enhancement } \\
\text { ratio (after } 48 \mathrm{~h})\end{array}$ \\
\hline Saline & - & 1.00 \\
As-I & 5.0 & $2.04^{b)}$ \\
& 10.0 & $1.31^{a)}$ \\
Laminarin & 50.0 & $1.40^{b)}$ \\
& 5.0 & 1.11 \\
Lentinan & 10.0 & $0.96^{a)}$ \\
& 50.0 & $1.16^{a)}$ \\
& 5.0 & $1.91^{b)}$ \\
& 10.0 & $1.47^{b)}$ \\
& 50.0 & $0.91^{a)}$ \\
\hline
\end{tabular}

$t$-Test: a) $p<0.05, b) p<0.01$

TABLE IV. Phagocytosis of Latex Particles

\begin{tabular}{|c|c|c|c|c|c|c|c|}
\hline \multirow[b]{2}{*}{ Sample } & \multirow[b]{2}{*}{$\begin{array}{c}\text { Dose } \\
(\mu \mathrm{g} / \mathrm{ml})\end{array}$} & \multicolumn{3}{|c|}{ Resident $\mathrm{M} \phi$} & \multicolumn{3}{|c|}{ MC-elicited $\mathbf{M} \phi$} \\
\hline & & $\begin{array}{c}\text { Phagocytic } \\
\text { enhancement } \\
\text { rate }(\%)\end{array}$ & $\begin{array}{c}0<X<10^{a)} \\
(\%)\end{array}$ & $\begin{array}{c}10<X^{a)} \\
(\%)\end{array}$ & $\begin{array}{c}\text { Phagocytic } \\
\text { enhancement } \\
\text { rate }(\%)\end{array}$ & $\begin{array}{c}\left.0<X<10^{a}\right) \\
(\%)\end{array}$ & $\begin{array}{c}10<X^{a)} \\
(\%)\end{array}$ \\
\hline Saline (control) & - & 1.00 & 60.0 & 8.0 & 1.00 & 61.7 & 10.7 \\
\hline As-I & 5.0 & $1.85 \pm 0.19$ & 51.6 & 25.4 & $1.89 \pm 0.30$ & 57.7 & 21.0 \\
\hline Laminarin & 5.0 & $1.21 \pm 0.18$ & 21.2 & 4.3 & $1.14 \pm 0.33$ & 15.6 & 3.7 \\
\hline Lentinan & 5.0 & $2.22 \pm 0.55$ & 61.3 & 24.3 & $2.34 \pm 0.93$ & 51.0 & 30.0 \\
\hline
\end{tabular}

a) $\mathrm{M} \phi$ phagocytizing 1 to 9 latex particles, or 10 or more particles.

(MC macrophages) were transferred to RPMI 1640 medium containing As-I at $1-50 \mu \mathrm{g} / \mathrm{ml}$ and phagocytosis of latex particles or fluorescein-Listeria was assessed after incubation for $42-78 \mathrm{~h}$. As shown in Fig. 1A, the phagocytosed latex particles increased in number in macrophages treated with As-I, especially after incubation for $80 \mathrm{~h}$. Phagocytosis of fluorescein-Listeria also increased (Fig. 1B). Maximum phagocytosis was observed when $1 \times 10^{6}$ cells/well were exposed to As-I at $5 \mu \mathrm{g} / \mathrm{ml}$ for $48 \mathrm{~h}$ as shown in Table III. Table IV summarizes the effects of As-I on the latex phagocytic activity of macrophages obtained without inducing agents and those induced with methylcellulose. The treatment with As-I approximately doubled (1.9) the phagocytic activity in both cases. In other words, although methylcellulose increased the yield of macrophages about 20 times, the macrophages so induced were activated by As-I just as well as those from the untreated source. When the effects of As-I on the phagocytic activity of macrophages were studied in vivo, macrophages were harvested $48-144 \mathrm{~h}$ after i.p. administration of $100 \mu \mathrm{g}$ of As-I to ICR mice and phagocytic action towards fluorescein-Listeria was assessed. The phagocytosis was approximately doubled $144 \mathrm{~h}$ after administration of As-I, in agreement with the results obtained in the absence of $\mathrm{T}$ cells and complement in vitro. Based on these results, it is considered that AsI directly activates macrophages even in the absence of $\mathrm{T}$ cells and complement. ${ }^{8,9)} \mathrm{A}$ nonantitumor polysaccharide, laminarin, did not exhibit such activities.

In summary, As-I, extracted from mycelia of Cochliobolus miyabeanus (Ascomycetes) and structurally similar to, but less branched than, lentinan, is able to inhibit allogeneic and syngeneic tumors in vivo. However, As-I did not inhibit the growth of transplants in mice when 
the tumor cells to be implanted were preliminarily exposed to As-I in vitro. Accordingly, the antitumor activity of As-I might be host-mediated like that of lentinan. It was confirmed that in macrophages cultured after collection from the peritoneal cavity, both phagocytic activity and spreading were approximately doubled by As-I, suggesting a stimulation of non-specific phagocytic activity of macrophages in vitro. Moreover, macrophages harvested from the peritoneal cavity of mice treated with As-I phagocytosed latex and Listeria particles as effectively as those directly treated with As-I in vitro did. Similar results have been obtained with $\beta$-glucans extracted from fruit bodies and mycelia of Basidiomycetes, but such activity has not been found in polysaccharides from Ascomycetes except for As-I from Cochliobolus miyabeanus. Our next paper will deal with the effects of As-I on activated macrophages, cytotoxic cells, natural killer cells and killer cells.

\section{References}

1) H. Nanba and H. Kuroda, Chem. Pharm. Bull., 35, 1285 (1987).

2) J. Zakny, G. Chihara and J. Fachet, Int. J. Cancer, 25, 371 (1980).

3) M. Robinovitch, R. E. Manejias, M. Russo and E. E. Abbey, Cellular Immunology, 29, 86 (1974).

4) J. Imanishi, Y. Yokota, T. Kishida, T. Mukainaka and A. Matsuo, Acta Viol., 19, 52 (1975).

5) J. Hamuro, M. Röllinghoff and H. Wagner, Cancer Res., 38, 3080 (1978).

6) J. Hamuro, M. Röllinghoff and H. Wagner, Immunol., 38, 328 (1978).

7) Y. Y. Maeda and G. Chihara, Gann, 64, 351 (1973).

8) A. G. Ehlenberger and V. Nussenzweig, J. Exp. Med., 145, 375 (1977).

9) J. Hamuro, U. Hadding and D. Bitter-Suermann, Immunol., 34, 695 (1978). 